\title{
Evidence for young carbonatitic metasomatism in the continental mantle root beneath the Middle Atlas, Morocco
}

\author{
Nadine Wittig $^{1,2}$, D. Graham Pearson ${ }^{1}$, Joel A. Baker ${ }^{3}$, Svend Duggen ${ }^{2,4}$, Kaj Hoernle ${ }^{4}$ \\ ${ }^{1}$ Department of Earth Sciences, Durham University, South Road, Durham, DH1 3LE, UK \\ ${ }^{2}$ Danish Lithosphere Centre, Øster Voldgade 10, 1350 Copenhagen K, DK
}

${ }^{3}$ School of Geography, Environment and Earth Sciences, Victoria University of Wellington, P. O. Box 600, Wellington, $N Z$

${ }^{4}$ Leibniz Institute of Marine Sciences, Kiel University, Wischhofstrasse. 1-3, 24148 Kiel, GER

\section{Introduction}

Intra-plate volcanism occurred c. 2 Ma in the Middle Atlas, Morocco and sampled the continental mantle root in the form of variably depleted peridotite xenoliths (olivine modal abundance 54-90\%). We present preliminary major element and Os isotope data for whole rock peridotites $(n=11)$ collected from a single Maar. In addition, constituent clinopyroxenes have been analyzed for trace element and $\mathrm{Pb}, \mathrm{Sr}, \mathrm{Nd}$ and Hf isotope systematics.

Whole-rock major and minor element data Major element systematics of these spinel-facies offcraton peridotites are variable and range from values more enriched than primitive mantle to depleted compositions $\left(\mathrm{Al}_{2} \mathrm{O}_{3}=4.9-1.87 \mathrm{wt} \%, \mathrm{SiO}_{2}=41.6-\right.$ $44.0 \mathrm{wt} \%)$.

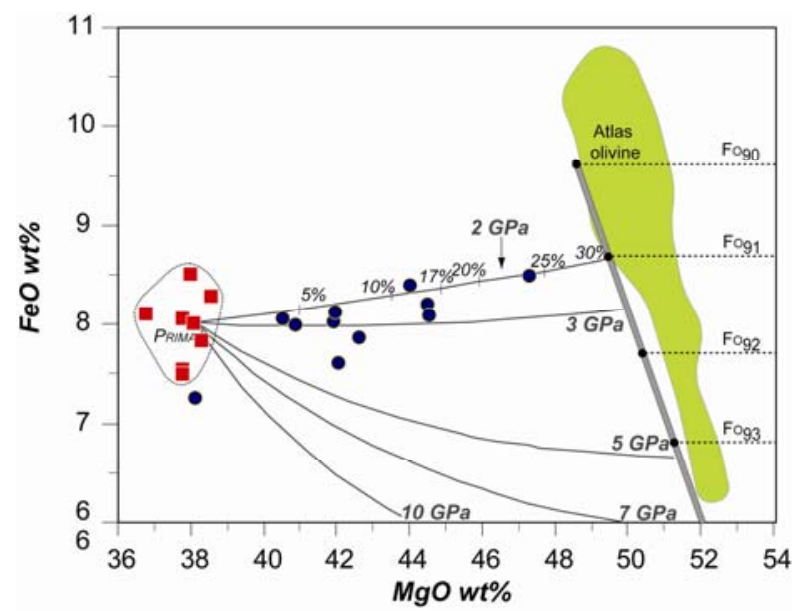

Fig. 1 Whole-rock FeO vs MgO of Middle Atlas peridotites. Polybaric melting trends for various pressures shown in GPa (Herzberg, 2004). Also shown is the range of olivine compositions in Middle Atlas xenoliths.
Generally, major elements such as $\mathrm{FeO}$ and $\mathrm{MgO}$ plot along $\sim 2 \mathrm{GPa}$ melt residue trends indicating up to $25 \%$ melt extraction, although some scatter does occur (Fig. 1). Some of this scatter could be explained by moderate addition of pyroxene. Considering such a spinel-facies melting scenario, Sc and $\mathrm{V}$ abundances confirm the range of melt extraction and indicate $\mathrm{fO}_{2}$ conditions ( NNO-1 to -2 , Fig. 2 ) similar to those anticipated for abyssal peridotites (Canil, 2002 \& 2004), thus suggesting depletion in a setting akin to present-day mid-ocean ridges.

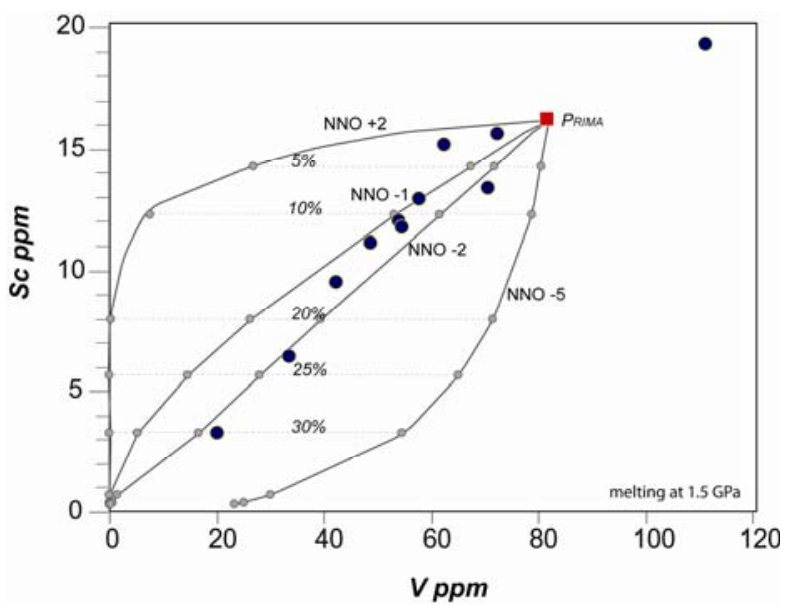

Fig. 2 Whole-rock Sc vs V. Melting trends calculated at 1.5 GPa for various $\mathrm{fO}_{2}(\mathrm{NNO}+2-\mathrm{NNO}-5)$ after Canil (2002 \& 2004).

\section{Os isotope systematics}

Whole-rock Os abundances and isotope ratios range from 0.8 to $6.0 \mathrm{ppb}$ and $\gamma \mathrm{Os}=-6.3$ to +1.8 . Os isotope systematics correlate broadly with indicators of depletion such as $\mathrm{Al}_{2} \mathrm{O}_{3}$ (Fig. 4). The timing of lithosphere formation in the Atlas region is poorly 
constrained and the Re-Os isotope systematics of these peridotites potentially provide evidence for a Paleoproterozoic stabilization of a variably depleted continental mantle root beneath the Middle Atlas. However, abyssal peridotites exhibit a similar range of Os isotopes (Harvey et al., 2006) and have decoupled Os isotope- $\mathrm{Al}_{2} \mathrm{O}_{3}$ systematics. Hence, more recent or repeated separation of the Middle Atlas lithospheric mantle from the convecting mantle cannot be excluded and further study into the evolution of Middle Atlas continental crust and the associated mantle roots is required.

One Middle Atlas peridotite is distinct from the bulk of these mantle xenoliths. It has major and minor element systematics that are more enriched than primitive mantle (Fig. $1 \& 2$ ) and falls off the trend formed by Os isotopes and $\mathrm{Al}_{2} \mathrm{O}_{3}$. This sample contains $\sim 23 \%$ clinopyroxene and its trace element abundances are the highest recorded in these peridotites.

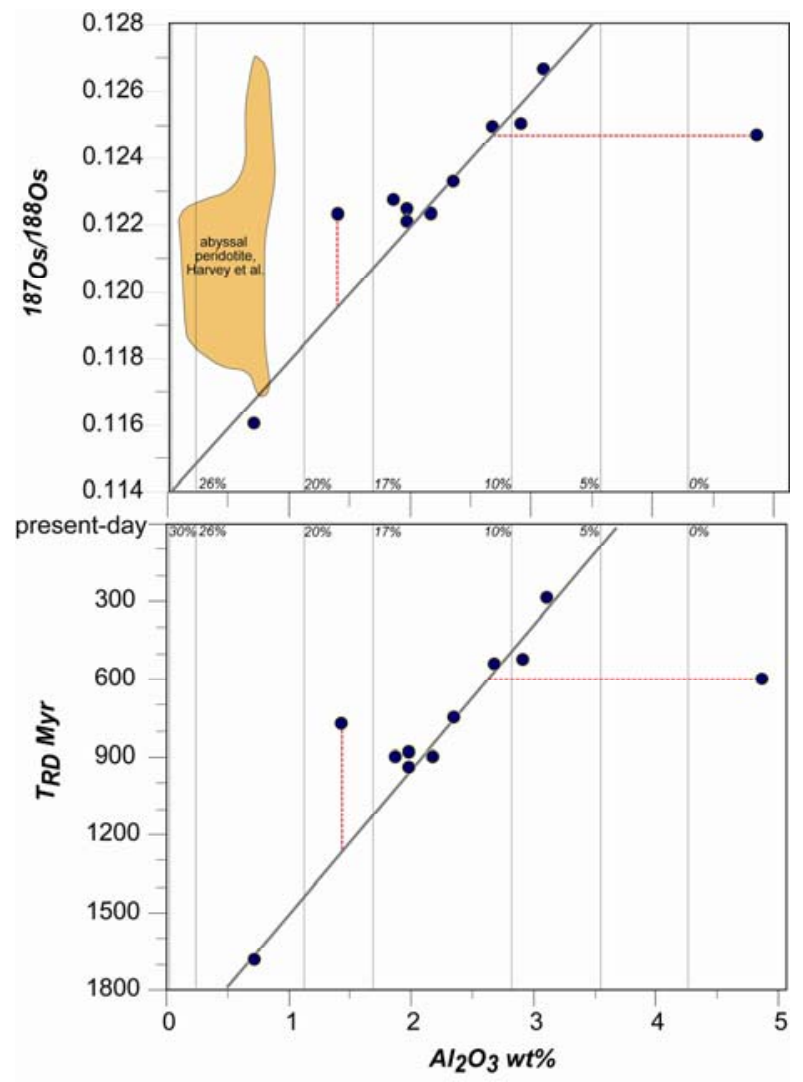

Fig. 3 Whole-rock ${ }^{187} \mathrm{Os} /{ }^{188} \mathrm{Os}$ and $\mathrm{T}_{\mathrm{RD}}$ model ages (Myr) vs $\mathrm{Al}_{2} \mathrm{O}_{3}$. Vertical lines indicate degree of depletion derived from $\mathrm{Al}_{2} \mathrm{O}_{3}$ at 2GPa (0-30\%, Herzberg, 2004).

\section{Mineral trace element data}

Handpicked and thoroughly leached clinopyroxenes separated from the Middle Atlas peridotites are marked by high abundances of incompatible trace elements although some variation in absolute concentration does occur. HFSE abundances appear comparatively low (Fig. 4). Overall, these lithophile trace element systematics are not suggestive of the significant melt depletion indicated by the major element systematics of the corresponding whole rocks. The incompatible trace elements in these xenoliths thus preserve predominantly a record of metasomatic enrichment. For example, Lu/Hf ratios of the Middle Atlas clinopyroxenes vary between 0.14 and 0.37 , which is consistent with clinopyroxene experiencing only 0 to 5\% spinel-facies melting (Wittig et al., 2007).

Notably, the least incompatible and relatively immobile $\mathrm{REE}, \mathrm{Lu}$, appears to preserve a record of shallow melting to the extent of $\sim 20 \%$. This suggests that Hf abundances (and elements more incompatible/mobile than $\mathrm{Lu}$ ) are substantially enriched despite the negative $\mathrm{Nb}-\mathrm{Ta}$ and $\mathrm{Zr}$-Hf anomalies exhibited by these clinopyroxenes. Moreover, the very high abundances of Th exclude hydrous fluid infiltration as a mechanism for generating the most recent enrichment recorded by these clinopyroxenes. In addition, ratios of elements with similar incompatibility during silicate melting and metasomatism (e.g. La/Ce, $\mathrm{Th} / \mathrm{U}, \mathrm{U} / \mathrm{Nb}, \mathrm{Nd} / \mathrm{Pb}$ ) are fractionated variably (e.g. $\mathrm{Nd} / \mathrm{Pb}=14-211$ ). These trace element systematics suggest that the metasomatic agent causing the enrichment of the Middle Atlas continental mantle clinopyroxenes had considerably more variable trace element systematics than putative mafic silicate melts, and that the metasomatic agent may have been carbonatitic liquids.

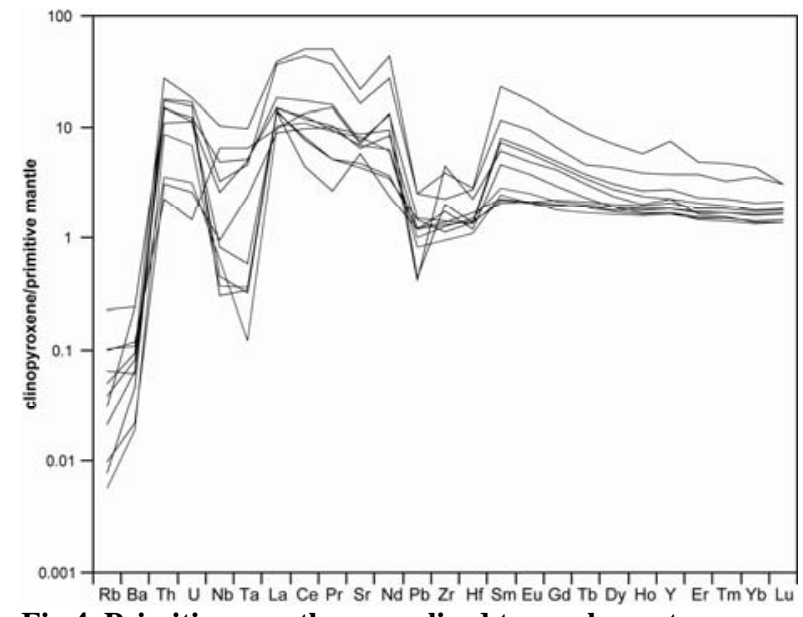

Fig.4 Primitive-mantle normalized trace element abundances of Middle Atlas clinopyroxene. Primitive mantle after Sun and McDonough.

\section{Clinopyroxene Sr-Hf-Nd isotope data}

$\mathrm{Sr}-\mathrm{Nd}$-Hf isotope systematics of these clinopyroxenes are relatively homogeneous and within the range previously reported from world-wide off-craton mantle clinopyroxene. The Middle Atlas xenoliths have somewhat unradiogenic $\mathrm{Nd}$ isotopes compared with most off-craton peridotites (Fig. 5). $\mathrm{Sr}$ and $\mathrm{Nd}$ isotope ratios $\left({ }^{87} \mathrm{Sr} /{ }^{86} \mathrm{Sr}=0.70317-0.70340 ; \varepsilon \mathrm{Nd}=+3.4-\right.$ +7.4 ) are well correlated and particularly $\mathrm{Nd}$ isotopes are more radiogenic than the host intra-plate volcanic ( $\varepsilon \mathrm{Nd}<4$, Duggen et al., unpublished data).

Clinopyroxene $\mathrm{Nd}$ isotopes and $\mathrm{Nd}, \mathrm{Sm}$ and $\mathrm{Eu}$ abundances indicate yield a tight mixing array $\left(\mathrm{R}^{2}=\right.$ 0.98) whereas $\mathrm{Sr}$ and $\mathrm{Hf}$ isotopes and abundances do not show such mixing relationships. Sr concentrations are highly variable (Fig. 5) both between samples and within single samples (Malarkey et al., this volume). 
Hf and $\mathrm{Nd}$ isotopes $(\varepsilon \mathrm{Hf}=+10.2-+18.6)$ do not correlate along the OIB correlation line but form a nearly perpendicular array. Here, the sample with least radiogenic $\mathrm{Nd}$ has the most radiogenic $\mathrm{Hf}$. The clinopyroxene lithophile isotope systematics including the supposedly more robust Hf isotope system - do not appear to preserve a Paleoproterozoic depletion event that could be deduced from Os wholerock isotope systematics. These $\mathrm{Sr}-\mathrm{Nd}-\mathrm{Hf}$ isotope systematics and particularly the decoupling of Hf from $\mathrm{Nd}$ and $\mathrm{Sr}$ isotopes also advocate carbonatitic fluids to have played an important role during the metasomatic evolution of this portion of continental lithospheric mantle.

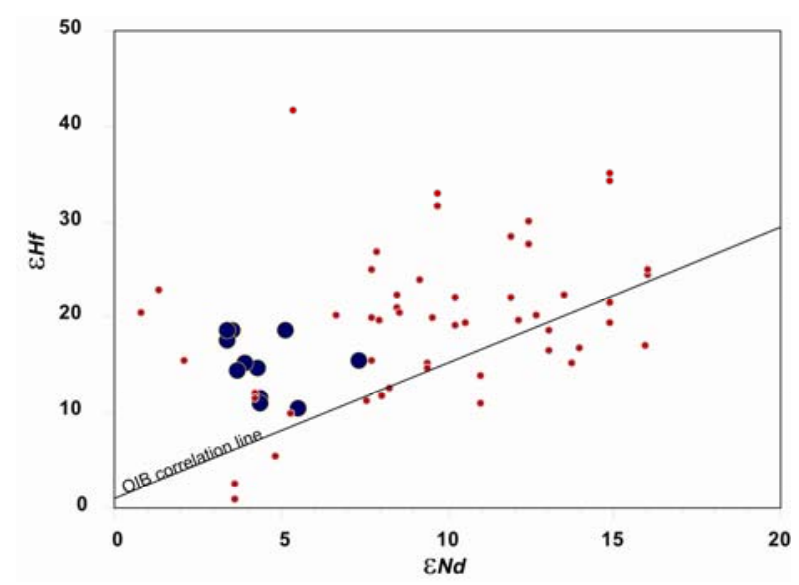

Fig. 5 Middle Atlas clinopyroxene $\varepsilon H f$ vs $\varepsilon N d$ in comparison to other off-craton clinopyroxenes (Wittig et al. 2007, Shaw et al., 2007). OIB correlation line after Johnson and Beard, 1993.

\section{Clinopyroxene U-Th-Pb isotope data}

$\mathrm{Pb}$ isotope systematics in clinopyroxenes are similarly homogeneous $\left({ }^{206} \mathrm{~Pb} /{ }^{204} \mathrm{~Pb} 19.93-20.25\right)$ to $\mathrm{Sr}-\mathrm{Nd}$ and $\mathrm{Hf}$ isotopes. No correlation of $\mathrm{Pb}$ isotopes with these other isotope systematics is evident. In comparison to other mantle clinopyroxene suites the samples from the Middle Atlas appear unusually homogeneous and the intra-plate volcanic rocks $\left({ }^{206} \mathrm{~Pb} /{ }^{204} \mathrm{~Pb}<19.72\right)$ are considerably less radiogenic.

The parent isotope ratios ${ }^{238} \mathrm{U} /{ }^{204} \mathrm{~Pb}$ and ${ }^{232} \mathrm{Th} /{ }^{204} \mathrm{~Pb}$ of these clinopyroxenes are variable and extend to extremely high values $(24-81,136-399$, respectively). Neither the U-Th-Pb nor Rb-Sr, Sm-Nd or Lu-Hf parent-daughter isotope ratios correlate with each other. This, and the extreme nature of ${ }^{238} \mathrm{U} /{ }^{204} \mathrm{~Pb}$ and ${ }^{232} \mathrm{Th} /{ }^{204} \mathrm{~Pb}$, coupled with their comparatively short half-lives require the latest metasomatism to have occurred very recently; probably within the past 20 Myrs. Importantly, back-modelling of the U-Th-Pb isotope systematics shows that the clinopyroxenes do not result from interaction with the host volcanic rocks. The percolating liquids causing the enrichment recorded by the clinopyroxene are required to be isotopically more extreme than the host lavas and also different from the exposed carbonatites (e.g. Tamazert) occurring in the Middle Atlas region.

\section{Summary}

The variably depleted spinel-facies continental mantle root beneath the Middle Atlas hosts lherzolites and harzburgites with major and minor element and Os isotope systematics that appear to record melt extraction of up to $25 \%$ in a shallow setting ( $\leq 2 \mathrm{GPa})$, possibly at a mid-ocean ridge. Constituent clinopyroxenes have enriched trace element systematics, with low HFSE and variable $\mathrm{Sr}$ abundances that are best reconciled if the most recent enrichment is assumed to result from carbonatitic liquids. $\mathrm{Sr}-\mathrm{Nd}-\mathrm{Hf}-\mathrm{Pb}$ isotopes are relatively homogeneous and only $\mathrm{Sr}-\mathrm{Nd}$ isotopes are well correlated. Generally, these lithophile isotope systematics are within the range of other off-craton mantle clinopyroxenes, and similar to the convecting mantle. However, ${ }^{238} \mathrm{U} /{ }^{204} \mathrm{~Pb}$ and ${ }^{232} \mathrm{Th} /{ }^{204} \mathrm{~Pb}$ are unusually high and considering the homogeneous $\mathrm{Pb}$ isotope record for these clinopyroxenes pervasive metasomatic enrichment must have occurred very recently.

\section{References:}

Canil, D., 2002. Vanadium in peridotites, mantle redox and tectonic environments: Archean to present. Earth and Planetary Science Letters, 195: 75-90.

Canil, D., 2004. Mildly incompatible elements in peridotites and the origins of mantle lithosphere. Lithos:, 77: 375-393.

Harvey, J. et al., 2006. Ancient melt extraction from the oceanic upper mantle revealed by Re-Os isotopes in abyssal peridotites from the Mid-Atlantic ridge. Earth and Planetary Science Letters, 244: 606-621.

Herzberg, C., 2004. Geodynamic information in peridotite petrology. Journal of Petrology, 45: 2507-2530.

Johnson, C.M. and Beard, B.L., 1993. Evidence from hafnium isotopes for ancient sub-oceanic mantle beneath the Rio Grande rift. Nature, 362: 441-444.

Malarkey, J., Pearson, D.G., Davidson, J.P., Wittig, N. 2008 Origin of Cr-diopside in peridotite xenoliths: Recent metasomatic addition revealed by a microsampling, trace element and Sr isotopic study of cratonic and off-craton peridotites. (This volume)

Shaw, J.E., Baker, J.A., Kent, A.J.R., Ibrahim, K.M. and Menzies, M.A., 2007. Chemical and isotopic character of Arabian lithospheric mantle- a source for intraplate volcanism? Journal of Petrology, 48: 1495-1512.

Sun, S.-s. and McDonough, W.F., 1989. Chemical and isotopic systematics of oceanic basalts: implications for mantle composition and processes. In: A.D. Saunders and M.J. Norry (Editors), Magmatism in the ocean basins. Geological Society Special Publications, London, pp. 313-345.

Wittig, N., Baker, J.A. and Downes, H., 2007. U-Th-Pb and Lu-Hf isotopic constraints on the evolution of subcontinental lithospheric mantle, French Massif Central. Geochimica et Cosmochimica Acta, 71: 1290-1311 